\title{
Infectivity, virulence, pathogenicity, host-pathogen interactions of SARS and SARS-CoV-2 in experimental animals: a systematic review
}

\author{
Jayanta Sarkar ${ }^{1,2} \cdot$ Rajdeep Guha ${ }^{2,3}$ \\ Received: 15 May 2020 / Accepted: 18 June 2020 / Published online: 10 July 2020 \\ (C) Springer Nature B.V. 2020
}

\begin{abstract}
The outbreak of the SARS-CoV-2 in mainland China with subsequent human to human transmission worldwide had taken up the shape of a devastating pandemic. The ability of the virus to infect multiple species other than humans has currently been reported in experimental conditions. Non-human primates, felines, ferrets, rodents and host of other animals could previously be infected in experimental conditions with SARS-CoV and recently with SARS-CoV-2, both virus using Angiotensin-converting-enzyme 2 receptor for cellular entry. The variations in sequence homology of ACE2 receptor across species is identified as one of the factors determining virulence and pathogenicity in animals. The infection in experimental animals with SARS-CoV or SARS-CoV-2 on most occasions are asymptomatic, however, the virus could multiply within the respiratory tract and extra-pulmonary organs in most of the species. Here, we discuss about the pathogenicity, transmission, variations in angiotensin-converting-enzyme 2 receptor-binding across species and host pathogen interactions of SARS and SARS-CoV-2 in laboratory animals used in research.
\end{abstract}

Keywords Coronaviruses $\cdot$ SARS-CoV-2 $\cdot$ Rodents $\cdot$ Non-human Primates $\cdot$ Transgenic Animals

\section{Introduction}

Coronaviruses (CoVs) are a family of viruses which were known to cause mild flu like symptoms in humans previously. However, these viruses harboured in wild mammals when transmitted to humans resulted in two pandemics of severe acute respiratory syndrome (SARS) and middle east respiratory syndrome (MERS) during the last two decades. The outbreak of severe acute respiratory syndrome corona virus 2 (SARS-CoV-2), popularly known as coronavirus disease 19 (COVID19) is the reoccurrence of infection by SARS related viruses which has been declared by the World Health Organisation (WHO) as a global pandemic. The outbreak occurred in a local sea food market in Wuhan, Hubei province in central China from a probable bat

Rajdeep Guha

rajdeep.guha@cdri.res.in

1 Division of Biochemistry, CSIR-Central Drug Research Institute, Lucknow, India

2 CSIR-Academy of Scientific and Innovative Research, New Delhi, India

3 Laboratory Animals Facility, CSIR-Central Drug Research Institute, Lucknow, India origin (Zhou 2020) which had a human to human transmission to more than 150 countries resulting in severe morbidity and mortality. The check of human to human transmission is only possible at present by following a set of hygienic principles, social distancing, isolation and quarantine of suspected patients as there are no validated therapeutics or a vaccine for prevention of the disease. Inoculation of SARS-CoV-2 in experimental animal reveal susceptibility of infection in cats, ferrets, dogs, hamsters, mouse and NHPs. The research revealing infectivity, pathogenicity and virulence of emerging infectious disease of SARSCoV and SARS-CoV-2 on experimental animals for development of drugs, identification of therapeutic targets, vaccine trials etc. are gaining momentum. Here, we review some similarity and differences with animal models of SARS-CoV and SARS-CoV2 infections as both the virus shares a homogeneity in infection pattern, pathogenicity, transmission and ACE2 receptor binding domains of spike protein.

\section{Threats arising out of SARS-L-CoV outbreaks}

Coronaviruses capable of infecting humans have been reported as early as 1890 s causing flu like symptoms. Prior to 
outbreak of COVID-19, six CoV strains affecting humans have been reported most of which are harbored in bats and some in rodents (Cui 2019) (Table 1). The outbreak of SARS in 2002 exhibited the ability of CoVs to cause widespread pandemic in human population, however the outbreaks were contained within a span of two years. Initially the palm civets were thought to be the reservoir host of this deadly virus, however when civets were inoculated with field isolates of human SARS-CoV rendered them infected indicating that civets are not the natural host of these CoVs (Wu 2005). Sample survey of 408 bats in 2004 from multiple species, genera and families in different provinces of China indicated a widespread seropositivity of SARS-CoV infection in bats indicating that bats are the reservoir host of several CoVs having the ability to cause severe respiratory syndromes $(\mathrm{Li}$ 2005b, Lau 2005). Nasopharyngeal, anal swabs and blood collected from 127 bats, 60 rodents and 20 monkeys at HKSAR region between 2004 and 2005 and subsequent isolation of CoVs revealed that $39 \%$ of Chinese horse shoe bats possess $\mathrm{CoVs}$ similar to SARS-CoVs. The genome analysis of the CoVs reveled the striking similarity of bat SARS-CoVs with that of human and civet SARS-CoVs (Lau 2005). Whole genome sequence analysis of two novel CoVs (RsSHC014 and Rs3367) isolated from Chinese horse shoe bats of Rhinolophidae family were closely related to the SARS$\mathrm{CoV}$ specially with respect to the receptor binding domain (RBD) of the viral spike protein, and that CoVs of Chinese horse shoe bats can directly be transmitted to humans without any intermediate host was recognized (Ge 2013). Identification and characterization of $\mathrm{CoVs}$ circulating in Chinese horse shoe bats possessed a severe threat to human population as evident from data and metagenomics study results obtained during the past 5 years (Ge 2013, Menachery 2015, He 2014).

\section{SARS coronaviral infections and pathogenicity in experimental animals}

The threats from CoVs had urged the scientific community to search for therapeutics, vaccines and diagnostics from the very initial stage resulting in experimental infection of animals with human or field isolates of the virus. The novelty of CoVs and differences in receptor binding domains of viral spike protein across multiple species was elusive on several occasions. SARS-CoVs uses the ACE2 receptor for entry into cells. Sequence homology of both ACE2 receptor varies across species and hence exhibition of human like symptoms in animals is not always observable in case of infection. Non-human primates (NHP) like African green monkeys (AGM), rhesus monkeys and cynomolgus monkeys when inoculated with of SARS-CoVs failed to show clinical signs of infection in all the species (only 1 out of 4 AGM showed high rectal temperature). Viral replication was evident in all the three species of monkeys and the replication was found to be higher in AGMs as compared to rhesus and cynomolgus. The early infection of broncho-tracheal epithelial cells and type 1 pneumocytes were also evident and consistent with observations in human SARS-CoV infection (McAuliffe 2004). Common marmosets infected with SARS-CoV showed mild clinical signs and symptoms of respiratory illness. Nonhemorrhagic diarrhea was observed in 7 out of 12 infected animals. Viral antigens could be detected in alveolar cells and type 1 pneumocytes along with multiple tissues indicating human like tissue distribution and viral multiplication of SARS-CoV (Greenough 2005). Cats and ferrets when inoculated with SARS-CoV did not show any clinical symptoms of illness although viral RNA could be detected in lungs, tracheobronchial lymph nodes and heart depicting asymptomatic illness (van den Brand 2008). Pigs and chickens were also asymptomatic after inoculation with human isolates although viral RNA could be detected in spleen in pigs and in blood, respiratory tract, kidneys of chicken (Weingartl 2004). Mice infected with SARS-CoV showed clinical signs of illness replicable of human like symptoms but young mice but do not show any clinical signs of illness, although virus multiplies in their respiratory tract (Roberts 2005a; Subbarao 2004). In a recent study, mice inoculated with an emerging strain of $\mathrm{CoV}$ WIV1-MA15, a bat origin novel CoV showed no symptoms or lethality of infection (Menachery 2016). Golden hamsters inoculated with a SARS-CoV strain shows no clinical signs of disease although viral RNA could be detected in respiratory tract (Roberts 2005b). The susceptibility, replication and pathogenicity is detailed in Table 2.

\section{SARS-CoV-2 infection and pathogenicity in experimental animals: recent findings}

Recent studies indicate that ferrets are susceptible to SARSCoV-2 infection with viral isolates from environmental and patient samples. The virus could be replicated in the upper respiratory tract and the virulence was restricted to mild disease without death. SARS-CoV-2 could bind to epithelial cells and type II pneumocytes of the lungs in ferrets but could not replicate within the lungs indicating that infection was restricted only to upper respiratory tract in ferrets (Shi 2020). Identical studies conducted in sub adult cats revealed that droplet transmission of SARS-CoV-2 can occur in cats and they are susceptible for infection however, infection is limited to upper respiratory tract in cats. Interestingly juvenile cats when inoculated with SARS-CoV-2 resulted in death or severe morbidity and histopathological lesions were observed in both upper and lower respiratory tract (Shi 2020). Dogs are mildly susceptible to SARS-CoV-2 infection whereas similar studies conducted on pigs, ducks and chickens revealed no 
Table 1 Reported coronaviral infection in humans

\begin{tabular}{llllll}
\hline CoV & Genus & Year of identification & Primary Receptor & Species of origin/Natural host & Ref \\
\hline HCoV-OC43 & Betacoronavirus & 1890 (probable) & 9-O-acetylated sialic acid & Rodent & Cui 2019 \\
HCoV-229E & Alphacoronavirus & 1965 & human aminopeptidase N & Bat & Cui 2019 \\
SARS-CoV & Betacoronavirus & 2003 & Angiotensin-converting-enzyme 2 & Bat & Cui 2019 \\
HCoV-NL63 & Alphacoronavirus & 2004 & Angiotensin-converting-enzyme 2 & Bat & Cui 2019 \\
HCoV-HKU1 & Betacoronavirus & 2005 & 9-O-acetylated sialic acid & Rodent & Cui 2019 \\
MERS-CoV & Betacoronavirus & 2012 & Dipeptidyl-peptidase 4 & Bat & Zhou 2020 \\
SARS-CoV-2 & Betacoronavirus & 2019 & Angiotensin-converting-enzyme 2 & Bat & \\
\hline
\end{tabular}

susceptibility of these species to SARS-CoV-2 infection (Shi 2020). Syrian hamsters when inoculated with SARS-CoV-2 showed similarity in disease pathogenesis, progression and transmissibility as observed in human infections. Severe infection of both upper and lower respiratory tracts, histopathological findings, cytokine and chemokine levels and changes in extra pulmonary organs were also evident (Chan 2020). Rhesus monkeys infected with SARS-CoV-2 showed viral presence in respiratory tract and gut (Bao 2020a). The findings are very necessary and important in the race for developing a therapeutic drug or vaccines against SARS-CoV-2. The susceptibility, replication and pathogenicity is detailed in Table 3.

\section{Host pathogen interactions of SARS-CoVs in experimental animals with respect to ACE2 RBD}

SARS-CoVs are assumed to have been originated through natural sources from other mammalian species (most likely from bat), it failed to mimic human clinical disease in animals and thereby limiting in depth of knowledge on infection process and possible modes of prevention and cure of this infection. The virus only exhibited transient viremia and milder symptoms in many of the model species while in some cases experimental infection ended without any clinical symptom or histopathological changes. In this context, high affinity virus receptor interaction might be one of the crucial factors that determines virulence of the pathogen in the host. This can be justified by the fact that experimental infection of hACE2 (functional receptor of SARS-CoV) expressing transgenic mice show clinical manifestations similar to human infection in comparison to the parental wild type mice (Tseng 2007). Likewise, murine $3 \mathrm{~T} 3$ cells expressing human ACE2 were more susceptible to SARS-CoV infection as compared to murine ACE2 (Li 2004). Host cellular invasion of SARS-CoV is mediated through interactions among distinct receptorbinding domains (RBD) on the SARS-CoV spike (S) protein and its functional receptor $\mathrm{ACE} 2$ wherein $\mathrm{S}$ protein binding domains are localized at 30-41 amino acid (aa) and 82-84 amino acid of ACE2 (Li 2005a). Therefore, the likelihood that sequence homology at $\mathrm{S}$ protein binding domains is the key determinant on susceptibility and clinical manifestation of SARS-CoV in animals. In line with this hypothesis, analysis of human ACE2 protein sequence with other potential host (experimental and reservoir) animals revealed more homology in bat vs. human and rhesus monkey than bat vs. other mammals at 30-41 aa region (Fig. 1). However, human and monkey ACE2 showed relatively less homology towards bat ACE2 at 82-84 aa region than cat, dog, ferret, marmoset, civet and raccoon. In both the $\mathrm{S}$ protein binding regions of ACE2, mouse and rat displayed distant homology for bat ACE2 than other species. Thus, it is likely that higher homology at binding domains in ACE2 receptor enabled SARS-CoVs for cross species infection from reservoir host to human during close proximity of human and bat in food markets in China. Similarly, the distant homology at $\mathrm{S}$ protein binding domains in mouse and rat ACE2 with bat and human ACE receptor possibly explains limited success in developing representative animal models for in depth study of SARS-CoV-2 infection. However, other host factors such as age, virome, host genetics, immune response pattern, previous and concomitant infections etc. may also play important role in mild or lack of clinical symptoms in animals (Sumbria 2019). Likewise, influence of other receptors like CD209L (Jeffers 2004) and Aminopeptidase N (APN) (Wentworth 2001) in efficiency of infection and replication of SARS-CoV in other host species cannot be excluded.

One of the conventional way of developing animal models of viral infection is adaptation of the pathogen in laboratory animal by serial passaging. This will eventually enable the virus to gain virulence in the animal host and thereby represent physiological responses of regular infection. Serial passaging of wild type virus in unnatural host also reduces its virulence towards normal host and is the traditional method of development of live attenuated vaccine for original host. However, adaptation of human virus in different host species may also impose potential risk of evolution of new viral strain which in turn may cause new epidemic. 


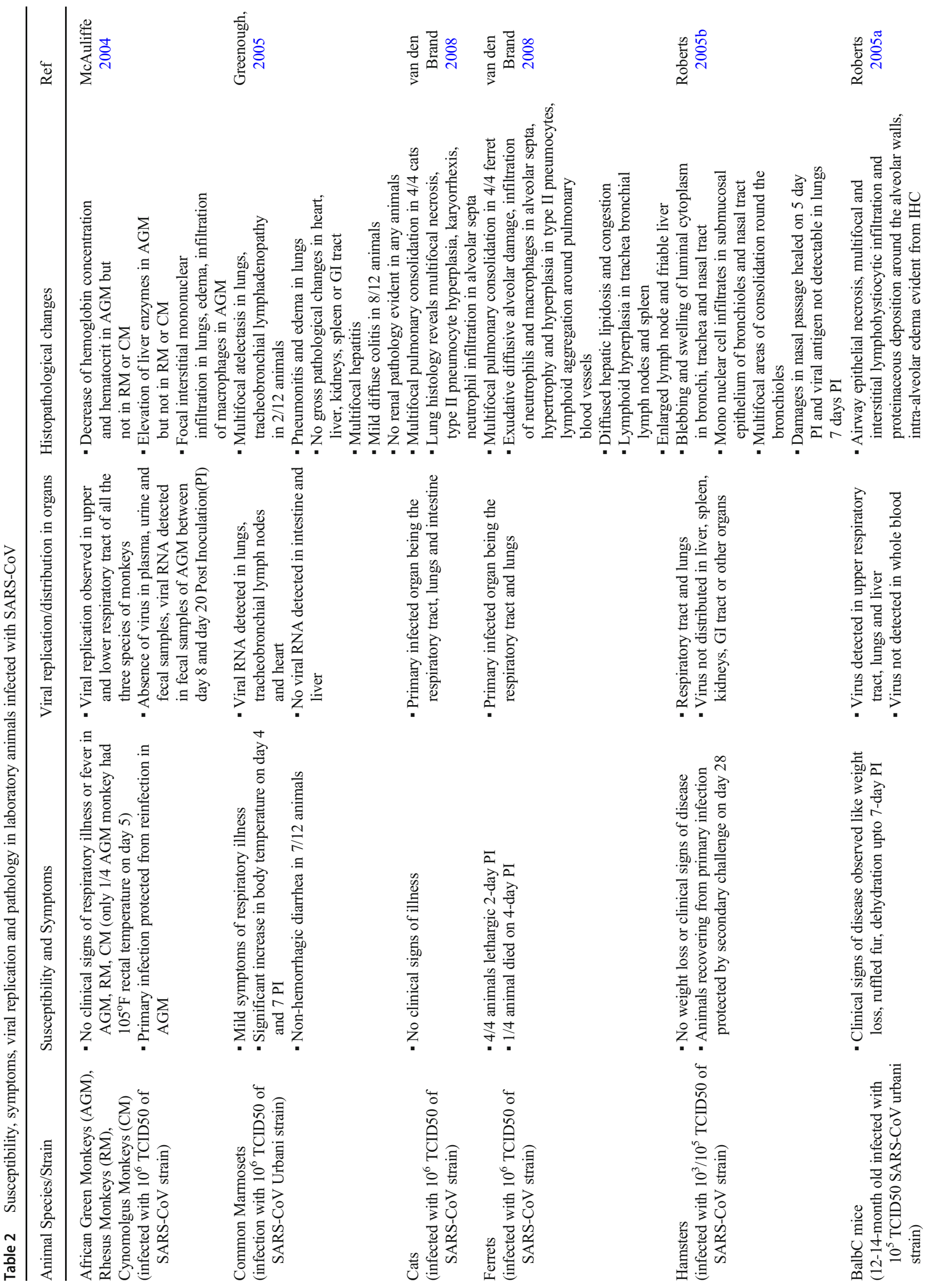




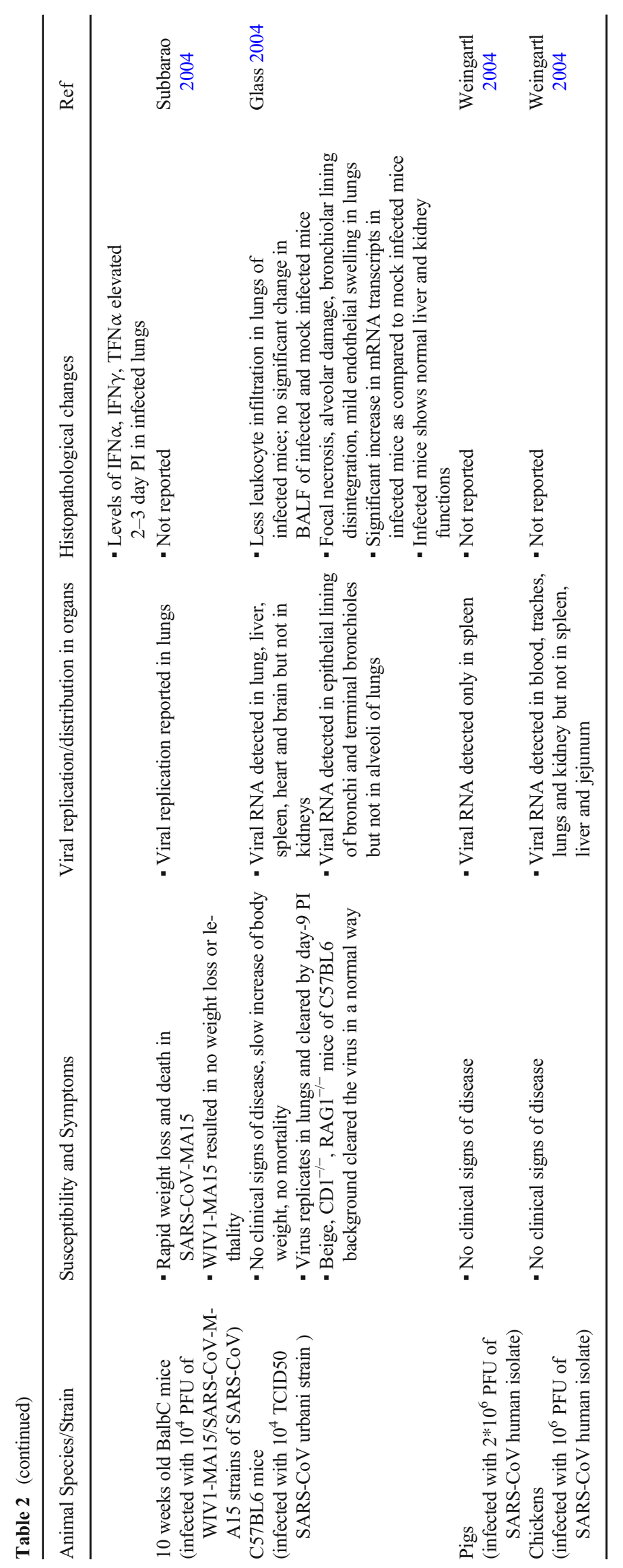


Table 3 Susceptibility, symptoms, viral replication and pathology in laboratory animals infected with SARS-CoV-2

\begin{tabular}{|c|c|c|c|c|}
\hline $\begin{array}{l}\text { Animal Species/ } \\
\text { Strain }\end{array}$ & Susceptibility and Symptoms & $\begin{array}{l}\text { Viral replication/distribution in or- } \\
\text { gans }\end{array}$ & Histopathological changes & Ref \\
\hline $\begin{array}{l}\text { Rhesus Monkeys } \\
\text { (infected with } 10^{6} \\
\text { TCID50 of } \\
\text { SARS-CoV-2 } \\
\text { strain) }\end{array}$ & $\begin{array}{l}\text { - Transient clinical signs of disease } \\
\text { like loss of body weight, hunched } \\
\text { posture, reduced appetite and } \\
\text { increased respiration rate } \\
\text { - No changes in body temperature }\end{array}$ & $\begin{array}{l}\text { - Viral RNA detected in nasal, } \\
\text { pharyngeal and rectal swabs } \\
\text { - Viral replication evident in lungs and } \\
\text { extra-pulmonary organs like heart, } \\
\text { spinal cord, gut, skeletal muscle and } \\
\text { urinary bladder }\end{array}$ & $\begin{array}{l}\text { - Moderate interstitial pneumonia, } \\
\text { macrophage accumulation in alveoli, } \\
\text { thickened alveolar septa, alveolar } \\
\text { epithelial degradation, } \\
\text { - bilateral ground glass opacification of } \\
\text { lungs }\end{array}$ & Bao 2020a \\
\hline $\begin{array}{l}\text { Cats } \\
\text { (infected with } 10^{5} \mathrm{PFU} \\
\quad \text { of CTan-H strain) }\end{array}$ & $\begin{array}{l}\text { - Respiratory droplet transmission } \\
\text { from infected cat to non-infected } \\
\text { cat }\end{array}$ & $\begin{array}{l}\text { - Viral RNA detected in trachea, lungs, } \\
\text { small intestine, tonsils, soft palate } \\
\text { and nasal turbinate at } 3 \text { day PI in } \\
\text { sub-adult cats } \\
\text { - Viral RNA detected in both upper } \\
\text { respiratory tract and lungs in } \\
\text { juvenile cats } \\
\text { - Respiratory droplet transmission } \\
\text { from infected cat to non-infected cat }\end{array}$ & $\begin{array}{l}\text { - Lesions observed in upper and lower } \\
\text { respiratory tract in juvenile cats }\end{array}$ & Shi 2020 \\
\hline $\begin{array}{l}\text { Ferrets } \\
\text { (infected with } 10^{5} \mathrm{PFU} \\
\quad \text { of F13-E strain and } \\
\text { CTan-H strain of } \\
\text { SARS-CoV-2) }\end{array}$ & $\begin{array}{l}\text { - } 1 / 3 \text { ferret developed loss of appetite } \\
\text { and fever }\end{array}$ & $\begin{array}{l}\text { - Viral RNA detected in tonsils, nasal } \\
\text { turbinate and soft palate of all ferrets } \\
\text { and not in any other organ } \\
\text { - Viral RNA detected in nasal washes } \\
\text { and rectal swab }\end{array}$ & $\begin{array}{l}\text { - Vasculitis, increased type II } \\
\text { pneumocytes, neutrophilic infiltration } \\
\text { in alveolar lumen and septa } \\
\text { - Lungs showing mild peribronchitis }\end{array}$ & Shi 2020 \\
\hline $\begin{array}{l}\text { Beagle Dogs } \\
\text { (infected with } 10^{5} \mathrm{PFU} \\
\text { of CTan-H strain) }\end{array}$ & - No symptoms reported & $\begin{array}{l}\text { - Viral RNA detected in rectal swabs } \\
\text { - Viral RNA not detected in any organ } \\
\text { or tissue }\end{array}$ & - Not reported & Shi 2020 \\
\hline $\begin{array}{l}\text { Pigs } \\
\text { (infected with } 10^{5} \mathrm{PFU} \\
\quad \text { of CTan-H strain) }\end{array}$ & - No symptoms reported & $\begin{array}{l}\text { - Viral RNA not detected in any } \\
\text { nasal/rectal swabs or any organs }\end{array}$ & - Not reported & Shi 2020 \\
\hline $\begin{array}{l}\text { Ducks } \\
\text { (infected with } 10^{5} \mathrm{PFU} \\
\quad \text { of CTan-H strain) }\end{array}$ & - No symptoms reported & $\begin{array}{l}\text { - Viral RNA not detected in any } \\
\text { nasal/rectal swabs or any organs }\end{array}$ & - Not reported & Shi 2020 \\
\hline $\begin{array}{l}\text { Chickens } \\
\text { (infected with } 10^{5} \mathrm{PFU} \\
\text { of CTan-H strain) }\end{array}$ & - No symptoms reported & $\begin{array}{l}\text { - Viral RNA not detected in any } \\
\text { nasal/rectal swabs or any organs }\end{array}$ & - Not reported & Shi 2020 \\
\hline $\begin{array}{l}\text { Hamsters } \\
\text { (infected with } 10^{5} \mathrm{PFU} \\
\text { of patient isolate of } \\
\text { SARS-CoV-2) }\end{array}$ & $\begin{array}{l}\text { - Animals exhibit disease symptoms } \\
\text { - Virus transmitted from infected to } \\
\text { close contact animals }\end{array}$ & $\begin{array}{l}\text { - High viral load in nasal turbinate, } \\
\text { trachea and lungs detected in culture } \\
\text { - Viral RNA detected in multiple } \\
\text { extra-pulmonary tissues but viral N } \\
\text { protein detected only in intestine } \\
\text { - Upregulation of cytokines and } \\
\text { chemokines in lungs }\end{array}$ & $\begin{array}{l}\text { - Mono-nuclear cell infiltration, focal cilia } \\
\text { loss, epithelial cellular swelling ob- } \\
\text { served in trachea } \\
\text { - Focal inflammation, pleural } \\
\text { invaginations, fluid exudate, diffused } \\
\text { alveolar destruction, hemorrhagic } \\
\text { alveolar collapse observed in lungs } \\
\text { - Epithelial cell necrosis, damaged } \\
\text { intestinal villi, increased mono-nuclear } \\
\text { cellular infiltration observed in intes- } \\
\text { tine } \\
\text { - Reduction in spleen size, mild focal } \\
\text { myocardial degeneration of heart }\end{array}$ & Chan 2020 \\
\hline
\end{tabular}

\section{hACE2 transgenic mice in SARS-CoV and SARS-CoV-2 experimentation}

The SARS-CoV and SARS-CoV-2 uses the ACE2 receptor for cellular entry hence transgenic mice bearing $h \mathrm{ACE} 2$ receptor is reported to be a good model for SARS-CoV multiplication. K18-hACE2 mice when inoculated with SARS$\mathrm{CoV}$ isolates showed signs and symptoms of severe infections. In K18-hACE2 mice CNS had been a major target for SARS-CoV infection which also mimics in SARS-CoV-2 infection as there were attempts to isolate this virus from cerebral microcirculations, cerebrospinal fluids and neuronal tissues (McCray 2007; Bao 2020b). A transgenic mice expressing hACE2 (AC70) showed similar types of infection like clinical signs of illness, weight loss, loss of breath and mortality and infection spread to multiple tissues including the brain (Tseng 2007). $h$ ACE2 mice infected with SARS-CoV-2 strain resulted in weight loss but no signs of respiratory illness were reported. Viral antigens could be detected in lungs and intestine but not in other major organs like brain, kidneys and liver (Bao 2020b). The susceptibility, replication and pathogenicity of SARS and SARS-CoV-2 is detailed in Table 4. 

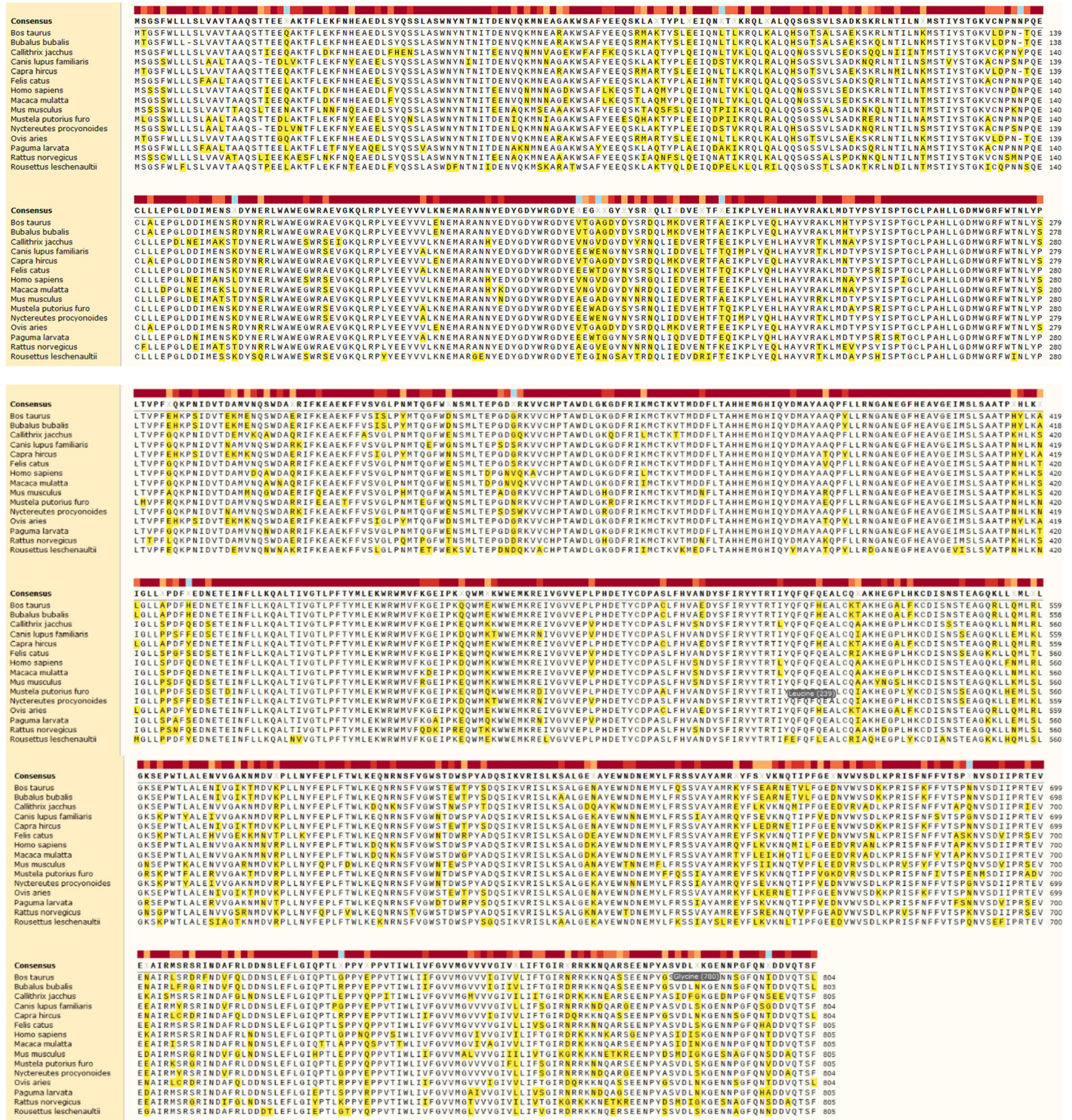

Fig. 1 Alignment of ACE2 amino acid sequences of different mammals. Analysis was performed by Clustal Omega programme using SnapGene software. Gene bank accession number of ACE2 proteins for indicated species are- H. sapiens, AB193260; R. leschenaultia, AB299376; M. mulatta, FJ170076; C. jacchus, XM_008988993.1; P. larvata,

\section{Discussions}

The genome sequence analysis of SARS-CoV-2 reveals that it shares a sequence identity of $79.6 \%$ to SARS-CoV and has $96 \%$ identity level of its genome with a novel bat $\mathrm{CoV}$
AY881174; N. procyonoides, EU024940; Mustela putorius furo, AB208708; F. catus, AB211997.1; Canis lupus familiaris, NM 001165260; R. norvegicus, AY881244; M. musculus, AK141604; B. taurus, NM_001024502.4.; B. bubalis, XM_006041540.2; C. hircus, XM 005701072; O. aries, XP 011961657

RatG13 indicating its bat origin. The receptor binding spike protein of SARS-CoV-2 had less than 75\% sequence homology with previously described all SARS related CoVs but the virus uses ACE2 receptor for cellular entry like other SARS$\mathrm{CoVs}$ and it did not show any affinity for other cellular 
Table 4 Susceptibility, symptoms, viral replication and pathology in hACE2 transgenic mice infected with SARS-CoV and SARS-CoV-2

\begin{tabular}{|c|c|c|c|c|}
\hline $\begin{array}{l}\text { Animal Species/ } \\
\text { Strain }\end{array}$ & $\begin{array}{l}\text { Susceptibility and } \\
\text { Symptoms }\end{array}$ & $\begin{array}{l}\text { Viral replication/distribution in } \\
\text { organs }\end{array}$ & Histopathological changes & Ref \\
\hline $\begin{array}{l}\text { K18-hACE2 mice } \\
\text { (infected with } \\
\quad 2.3 \times 10^{4} \mathrm{PFU} \text { of } \\
\text { SARS-CoV } \\
\text { strain) }\end{array}$ & $\begin{array}{l}\text { - Shows severe signs of } \\
\text { disease like weight loss, } \\
\text { lethargy and labored } \\
\text { breathing } \\
\text { - SARS-CoV not transmit- } \\
\text { ted from infected to } \\
\text { non-infected mice }\end{array}$ & $\begin{array}{l}\text { - viral titers detected in lungs, } \\
\text { brain } \\
\text { - Virus not detected in liver, } \\
\text { small intestine and kidneys } \\
\text { - Detection of viral antigen in } \\
\text { cerebrum, cerebellum, } \\
\text { thalamus, brainstem, } \\
\text { olfactory balb }\end{array}$ & $\begin{array}{l}\text { - Perivascular and peribronchiolar inflammation } \\
\text { - Epithelial cell sloughing, hemorrhage, congestion } \\
\text { in alveolar septa } \\
\text { - Intense neutrophilic infiltration, necrotizing } \\
\text { bronchopnemmonia } \\
\text { - Upregulation of cytokines and chemokines in lungs } \\
\text { and brain }\end{array}$ & $\begin{array}{c}\text { McCray } \\
2007\end{array}$ \\
\hline $\begin{array}{l}h \text { ACE2-AC70 mice } \\
\text { (infected with } \\
2 \times 10^{5} / 10^{3} \\
\text { TCID50 of } \\
\text { SARS-CoV } \\
\text { strain) }\end{array}$ & $\begin{array}{l}\text { - Symptoms of weight loss, } \\
\text { lethargy, ruffled fur, } \\
\text { shallow breathing } \\
\text { - } 100 \% \text { Mortality 8-day PI }\end{array}$ & $\begin{array}{l}\text { - Viral replication detected in } \\
\text { lungs and brain, low level of } \\
\text { viremia detected in blood } \\
\text { - Virus could be detected in } \\
\text { bowels, nasal washes and } \\
\text { liver but not in throat swabs } \\
\text { - Virus not detected in heart, } \\
\text { kidneys, urine, spleen }\end{array}$ & $\begin{array}{l}\text { - Moderate interstitial pneumonitis, alveolar wall } \\
\text { thickening, presence of cellular debris and } \\
\text { macrophages in alveolar sacks and airways } \\
\text { - Cytoplasmic swelling, blebbing in } \\
\text { bronchoepithelial cells } \\
\text { - Viral antigen detected in ganglion cells and } \\
\text { vascular smooth muscles of lungs and blood } \\
\text { vessels, glial cells of CNS } \\
\text { - Elevated levels of cytokines and chemokines in } \\
\text { lungs }\end{array}$ & Tseng 2007 \\
\hline $\begin{array}{l}\text { HFH4- } h \text { ACE2 } \\
\text { mice } \\
\text { (infected with } 10^{5} \\
\text { PFU of } \\
\text { SARS-CoV } \\
\text { urbani strain) }\end{array}$ & $\begin{array}{l}\text { - Rapid weight loss, and } \\
\text { death between day 4-5 }\end{array}$ & $\begin{array}{l}\text { - Viral replication in brain, } \\
\text { lungs }\end{array}$ & - Not reported & $\begin{array}{l}\text { Menachery } \\
2016\end{array}$ \\
\hline $\begin{array}{l}h \text { ACE2-mice } \\
\text { (infected with } 10^{5} \\
\text { TCID50 of } \\
\text { SARS-CoV-2 } \\
\text { strain) }\end{array}$ & $\begin{array}{l}\text { - Slight weight loss and } \\
\text { bristled fur, no other } \\
\text { clinical signs reported }\end{array}$ & $\begin{array}{l}\text { - Viral RNA detectable in } \\
\text { lungs, intestine } \\
\text { - Virus could be isolated from } \\
\text { lungs in Vero E6 cell line } \\
\text { - Viral antigens not detected in } \\
\text { kidneys, liver, spleen, } \\
\text { myocardium, testis or brain }\end{array}$ & $\begin{array}{l}\text { - Dark reddish-purple areas and nodules found in } \\
\text { lungs } \\
\text { - Moderate interstitial pneumonia, thickening of } \\
\text { alveolar septa, infiltration of inflammatory cells in } \\
\text { alveolar cavities, high infiltration of macrophages, } \\
\text { neutrophils and lymphocytes in perivascular } \\
\text { region } \\
\text { - Swollen, degenerated Broncho epithelial cells }\end{array}$ & Bao 2020b \\
\hline
\end{tabular}

binding domains like DPP4 and aminopeptidase N. Some SARS-CoV-2 genes shows less than $80 \%$ sequence identity with SARS-CoV. There are differences in the spike protein gene between SARS-CoV-2 and SARS-CoV in four out of five key residues of receptor binding motif and three short insertions in N-terminal domain of S-gene (Zhou 2020).

Non-human primates showed no clinical signs of respiratory illness when infected with SARS-CoV strain, however in infection with SARS-CoV-2 strain, initial clinical signs like loss of body weight, hunched posture, loss of appetite are evident. Viral replication in monkeys is also evident in respiratory organs rendering histopathological changes in lungs but extra-pulmonary replication is more evident and pronounced in SARS-CoV-2 infection as compared to SARS-CoV indicating more virulence and pathogenicity. Clinical symptoms and pathological manifestations were observed in common marmosets in SARS-CoV infection but data pertaining to SARSCoV-2 infection in marmosets is currently not reported.

Higher virulence and fatality of juvenile cats infected with SARS-CoV-2 is reported. Cats are one of the most popular companion animals of humans and are highly vulnerable in
SARS-CoV-2 pandemic. There is also a possibility of reverse transmission of virus from infected cats to humans although sufficient data is not available to establish this fact. Ferrets infected with both the viruses show similarities of clinical illness, but infection in ferrets by SARS-CoV-2 is restricted to upper respiratory tract while viral RNA could also be detected in lungs of ferrets in SARS-CoV infection. Hamsters challenged with SARS-CoV strain showed no clinical signs of illness and weight loss but infection with SARS-CoV-2 results in clinical signs of disease. Pigs and chickens are asymptomatic in infections with both SARS-CoV and SARS-CoV-2.

It is also quite notable that the SARS-CoV-2 patients with associated heart disease, diabetes and other systemic disease are more susceptible to fatality. It may be because of multiple disruptions in the system as a result of neurological invasion of SARS-CoV-2 (Baig 2020). Spread of SARS-CoV to multiple organs including brain was demonstrated in K18-hACE2 and hACE2 (AC70) mice from actual site of infection i.e. lungs but interestingly hACE2 transgenic mice infected with SARS-CoV-2 show no presence of viral antigens in brain. SARS-CoV-2 is shown to be highly virulent than SARS- 
$\mathrm{CoV}$ infection resulting in severe signs of respiratory illness and mortality, however, mild symptoms are observed in hACE2 transgenic mice while infected with SARS-CoV-2.

It is quite evident from current knowledge that virulence in animal models with SARS-CoV-2 infection is higher in some of the species as compared to SARS-CoV infection but hACE2 mice are more permissive to infection with SARS$\mathrm{CoV}$ as compared to SARS-CoV-2. The background of strains, age, sex etc. must also be evaluated in species as viral invasion and replication does not solely depend on the entry of virus within the host but host adaptability and immune status also. The testing of new chemical entities, drug repurposing and vaccine evaluations count a good preclinical animal experimentation data, it is high time that research should be directed in searching for reliable and reproducible animal models for emerging coronaviral infections.

Acknowledgements The authors acknowledge the support of CSIR, New Delhi, India and CSIR-CDRI, Lucknow, India. The manuscript bears CSIR-CDRI communication number 10089.

Author contributions JS and RG reviewed the literature and drafted the manuscript.

\section{Compliance with ethical standards}

Conflict of interest The authors declare no conflict of interest.

\section{References}

Baig AM, et al (2020) Evidence of the COVID-19 virus targeting the CNS: Tissue distribution, host-virus interaction, and proposed neurotropic mechanisms. ACS Chem Neurosci 11:995-998. https://doi. org/10.1021/acschemneuro.0c00122

Bao L, et al (2020a) Reinfection could not occur in SARS-CoV-2 infected rhesus macaques. bioRxiv 2020a.03.13.990226. 10.1101/ 2020a.03.13.990226

Bao L, et al (2020b) The pathogenicity of SARS-CoV-2 in hACE2 transgenic mice. Nature. https://doi.org/10.1038/s41586-020-2312-y

Chan JF-W, et al (2020) Simulation of the clinical and pathological manifestations of Coronavirus Disease 2019 (COVID-19) in golden Syrian hamster model: implications for disease pathogenesis and transmissibility. Clin Infect Dis. https://doi.org/10. 1093/cid/ciaa325

Cui J, et al (2019) Origin and evolution of pathogenic coronaviruses. Nat Rev Microbiol 17:181-192. https://doi.org/10.1038/s41579-0180118-9

Ge X-Y, et al (2013) Isolation and characterization of a bat SARS-like coronavirus that uses the ACE2 receptor. Nature 503:535-538. https://doi.org/10.1038/nature12711

Glass WG, et al (2004) Mechanisms of host defense following severe acute respiratory syndrome-coronavirus (SARS-CoV) pulmonary infection of mice. J Immunol 173:4030-4039. https://doi.org/10. 4049/jimmunol.173.6.4030

Greenough TC, et al (2005) Pneumonitis and multi-organ system disease in common marmosets (Callithrix jacchus) infected with the severe acute respiratory syndrome-associated coronavirus.
Am J Pathol 167:455-463. https://doi.org/10.1016/S00029440(10)62989-6

$\mathrm{He} \mathrm{B}$, et al (2014) Identification of diverse alphacoronaviruses and genomic characterization of a novel severe acute respiratory syndromelike coronavirus from bats in China. J Virol 88:7070-7082. https:// doi.org/10.1128/JVI.00631-14

Jeffers SA, et al (2004) CD209L (L-SIGN) is a receptor for severe acute respiratory syndrome coronavirus. Proc Natl Acad Sci U S A 101:15748-15753. https://doi.org/10.1073/pnas. 0403812101

Lau SKP, et al (2005) Severe acute respiratory syndrome coronavirus-like virus in Chinese horseshoe bats. Proc Natl Acad Sci U S A 102: 14040-14045. https://doi.org/10.1073/pnas.0506735102

Li W, et al (2004) Efficient replication of severe acute respiratory syndrome coronavirus in mouse cells is limited by murine angiotensinconverting enzyme 2. J Virol 78:11429-11433. https://doi.org/10. 1128/JVI.78.20.11429-11433.2004

Li W, et al (2005a) Receptor and viral determinants of SARS-coronavirus adaptation to human ACE2. EMBO J 24:1634-1643. https://doi. org/10.1038/sj.emboj.7600640

Li W, et al (2005b) Bats are natural reservoirs of SARS-like coronaviruses. Science 310:676-679. https://doi.org/10.1126/ science.1118391

McAuliffe J, et al (2004) Replication of SARS coronavirus administered into the respiratory tract of African Green, rhesus and cynomolgus monkeys. Virology 330:8-15. https://doi.org/10.1016/j.virol.2004. 09.030

McCray PB, et al (2007) Lethal infection of K18-hACE2 mice infected with severe acute respiratory syndrome coronavirus. J Virol 81:813821. https://doi.org/10.1128/JVI.02012-06

Menachery VD, et al (2015) SARS-like cluster of circulating bat coronavirus pose threat for human emergence. Nat Med 21:1508-1513. https://doi.org/10.1038/nm.3985

Menachery VD, et al (2016) SARS-like WIV1-CoV poised for human emergence. Proc Natl Acad Sci U S A 113:3048-3053. https://doi. org/10.1073/pnas.1517719113

Roberts A, et al (2005a) Aged BALB/c mice as a model for increased severity of severe acute respiratory syndrome in elderly humans. J Virol 79:5833-5838. https://doi.org/10.1128/JVI.79.9.5833-5838. 2005

Roberts A, et al (2005b) Severe acute respiratory syndrome coronavirus infection of golden Syrian hamsters. J Virol 79:503-511. https://doi. org/10.1128/JVI.79.1.503-511.2005b

Shi J, et al (2020) Susceptibility of ferrets, cats, dogs, and other domesticated animals to SARS-coronavirus 2. Science. https://doi.org/10. 1126/science.abb7015

Subbarao K, et al (2004) Prior infection and passive transfer of neutralizing antibody prevent replication of severe acute respiratory syndrome coronavirus in the respiratory tract of mice. J Virol 78:35723577. https://doi.org/10.1128/jvi.78.7.3572-3577.2004

Sumbria D, et al (2019) Factors affecting the tissue damaging consequences of viral infections. Front Microbiol 10:2314. https://doi. org/10.3389/fmicb.2019.02314

Tseng C-TK, et al (2007) Severe acute respiratory syndrome coronavirus infection of mice transgenic for the human Angiotensin-converting enzyme 2 virus receptor. J Virol 81:1162-1173. https://doi.org/10. 1128/JVI.01702-06

van den Brand JMA, et al (2008) Pathology of experimental SARS coronavirus infection in cats and ferrets. Vet Pathol 45:551-562. https://doi.org/10.1354/vp.45-4-551

Weingartl HM, et al (2004) Susceptibility of pigs and chickens to SARS coronavirus. Emerg Infect Dis 10:179-184. https://doi.org/10.3201/ eid1002.030677

Wentworth DE, et al (2001) Molecular determinants of species specificity in the coronavirus receptor aminopeptidase N (CD13): influence of 
N-linked glycosylation. J Virol 75:9741-9752. https://oi.org/10. 1128/JVI.75.20.9741-9752.2001

Wu D, et al (2005) Civets are equally susceptible to experimental infection by two different severe acute respiratory syndrome coronavirus isolates. J Virol 79:2620-2625. https://doi.org/10.1128/JVI.79.4. $2620-2625.2005$
Zhou P, et al (2020) A pneumonia outbreak associated with a new coronavirus of probable bat origin. Nature 579:270-273. https://doi.org/ 10.1038/s41586-020-2012-7

Publisher's Note Springer Nature remains neutral with regard to jurisdictional claims in published maps and institutional affiliations. 